\title{
Peculiarities of yield formation of potato depending on the climate conditions of the western forest steppe of Ukraine
}

\author{
Ivan Shuvar ${ }^{1}$, Hanna Korpita ${ }^{1}$, Volodymyr Balkovskyi ${ }^{1}$, and Antin Shuvar ${ }^{2, *}$ \\ ${ }^{1}$ Lviv National Agrarian University, 80381 V. Velykoho1, Dublyany, Ukraine \\ ${ }^{2}$ Institute of Agriculture of the Carpathian Region NAAS, Hrushevskogo Str., Oboroshino village, \\ 81115 Pustomytivskii, Lvivska region, Ukraine
}

\begin{abstract}
The study of the problem of the influence of climatic factors on the conditions of formation of productivity of agrocenoses has important ecological and national economic value as the estimation of dynamics of productivity of the main crops of Ukraine according to change of meteorological factors is especially actual in the conditions of global climate changes. The correlation dependence of the formation of the yield of potato tubers on the climatic factors of the western forest-steppe of Ukraine has been analyzed. Te features of the formation of potato yields depending on the amount of active temperatures, the amount of precipitation during the growing season of the crop and the reserves of productive moisture in the arable $(0-30 \mathrm{~cm})$ soil layer in the budding phase and during the harvesting of the crop have been established.
\end{abstract}

\section{Inroduction}

In the technology of growing crops, climatic factors have a special impact directly on the course of processes in the ecosystem, conditions and life expectancy of organisms, their distribution, activity, reproduction. Climatic conditions of the Forest-Steppe zone are characterized by relatively mild winters, moderately humid and warm summers. Such conditions are particularly favorable for the formation of high productivity of potatoes in biologized agrocenoses, even in global climate change $[1,2,3,4,5]$.

The formation of crop yields largely depends on the course of such vital cultivation processes as the intensity of photosynthesis and respiration, absorption of water and minerals, transpiration $[6,7,8,9,10]$.

Precipitation is an important climatic resource for the formation of soil moisture reserves that affect plant growth. That is why sufficient reserves of productive moisture for use by plants during the growing season are an important indicator and factor in increasing yields $[1,2]$.

Experts from the European Commission's Science and Knowledge Service believe that climate change (rising temperatures and uneven distribution of precipitation) in Europe will

\footnotetext{
*Corresponding author: korpita@ukr.net
} 
significantly affect crop yields, increase the impact of drought, forest fires, river floods and increase sea levels [8-12].

The results of the analysis of climate scenarios of scientists [1, 2, 3, 6, 8,12-15] show that:

- Temperatures have a clear upward trend across Europe. At the end of the XXI century, a much more intense rise in temperature will be felt;

- temperature rise is reflected in all climatic indicators. Based on this variable, there is a clear trend of thermal elongation of the growing season, its beginning is noticeable, the number of days with a minimum temperature below $0{ }^{\circ} \mathrm{C}$ decreases, and the number of days with a maximum temperature above $25^{\circ} \mathrm{C}$ increases;

- trends in changes in precipitation are less pronounced. The developed perspective models are approved, which predicted some increase in the amount of winter precipitation and their decrease in the summer period by the end of the century.

Our analysis of the manifestation of climate change, which has already been recorded in Ukraine, showed that:

- The average temperature during the January implementation of 1991-2010 was 2 degrees higher than in 1961-1990; in July - higher by 1-1.5 degrees. The maximum and minimum recorded temperatures also increase.

- Shifted climatic periods: spring and autumn air temperature transitions through 0 degrees earlier on average for 1-6 days depending on the region

- The amount of precipitation in winter has decreased, in spring and summer and changed not significantly, and increased in autumn. There have been more cases when half or the monthly norm of the precipitation falls within a few hours.

- Increased number of natural meteorological phenomena: heavy rain, strong wind, heavy snowfall, heavy fog, large hail, squall, heavy ice, heavy blizzard.

- Increased number of waves of heat - periods during which the maximum air temperature exceeds 5 consecutive days exceeds the average maximum air temperature on that day during of 1961-1990 at 5 degrees.

The problem of managing the dependence of the biological productivity of the agroecosystem on the complex influence of meteorological factors is relevant at the present stage of agriculture and requires additional study.

The purpose of the study is to identify the dependence of potato agrocenosis on the influence of meteorological factors (air temperature, precipitation, reserves of productive moisture in the soil) in the western forest-steppe of Ukraine.

The need for moisture for potato plants is determined by the level of saturation of its tissues with water (75-85\%), the level of development and condition of the soil in the area of the root system and the formation of different levels of tuber yield.

In different periods of the growing season of potato plants, the need for water is different. During the period of germination of potato plants, the moisture of the mother tuber is sufficient, which does not depend on the moisture content in the soil and needs only heat and oxygen. Potatoes withstand drought in this period is not as painful as in other growing seasons. Therefore, during early spring planting, dry spring with rapid warming of the soil is favorable for the growth of potato plants. Under conditions of excessively dry soil, moisture in the mother tuber may not be enough for germination, tuber development deteriorates, and the emergence of seedlings is delayed [15-18].

Based on many years of research (2011-2020), we found that the critical period for potato plants enters the phase of budding and mass tuber formation [10,14,18-21].

Prior to the formation of potato tubers, the need for moisture is insignificant, but by the end of the flowering phase, a sufficient supply of water is required. In the process of increasing the aboveground mass and increasing the leaf surface area, the need to provide potato plants with moisture increases and reaches its maximum in the budding and 
flowering phase, when the formation of tubers continues, which is also confirmed by our mathematical and statistical calculations.

On average, during the growing season of the culture for the formation of $1 \mathrm{~kg}$ of tubers consumed 80-100 liters of water. The largest increase in aboveground mass occurs at soil moisture $70-85 \%$ of the lowest moisture content (HB), and the growth of tubers - at a humidity of $85-95 \% \mathrm{HB}$. At the end of the growing season, the need for water decreases again. The high water content in the soil promotes the growth of tubers, but they are formed with a low dry matter content, have a loose skin and low shelf life.

Despite the high requirements for soil moisture, potato plants can withstand short periods of drought. With the onset of drought, the productivity of potatoes decreases, but the plants do not die, and the formation of tubers is restored. Under conditions of prolonged drought (soil moisture below 50\% HB) yields are significantly reduced [14, 21].

Lack of moisture in the soil during the formation of tubers leads to a slowdown in the formation of stolons and a decrease in the number of formed tubers, and with a complete deficit of moisture, the growth of tubers stops. Under such conditions, the size of the tubers and yields decrease, their skin hardens and corks [6, 8, 14, 21].

Potato plants also react negatively to waterlogging of the soil. Under such conditions, the content of dry matter and starch in the tubers decreases, the plants are significantly affected by disease. Excessive soil moisture during the ripening of tubers inhibits this process, and lack of air leads to suffocation of tubers and unfit for consumption [14, 21].

\section{Material and methods}

The study was performed during 2011-2020 on a dark gray forest podzolic medium loam soil of the research field of Lviv National Agrarian University (Dublyany, Lviv region, Zhovkva district). According to the results of agrochemical analysis of the soil in the agrochemical laboratory of the university, the following indicators were obtained: humus profile to a depth of 55-70 $\mathrm{cm}$ with a humus content in the arable $(0-30 \mathrm{~cm})$ layer of 2.0 $2.5 \%$. The reaction of the soil solution is weakly acidic $(\mathrm{pH}-5.5-6.5)$, hydrolytic acidity 2.0-4.2 mg-eq / $100 \mathrm{~g}$ of soil. The degree of saturation with bases is $75-90 \%, \mathrm{~N}$ (according to Cornfield) - 51.2, P2O5 (according to Chirikov) - 92 and K2O (according to Maslova) $107 \mathrm{mg} / \mathrm{kg}$ of soil.

Alternation of crops in crop rotation according to the scheme: peas (Gotovsky variety) winter wheat (Smuglyanka variety) - potatoes (Volya variety) - spring barley (Sontsedar variety).

The following fertilizer rates were applied to crops in crop rotation: peas (N45P45K45) - winter wheat (N60P60K60) - potatoes (manure $30 \mathrm{t} /$ ha + N90P90K90) - spring barley (N60P60K60).

\section{Results and discussion}

Given the significant impact of global climate change on agrocenoses and the environment in general, one of the main factors influencing potato yield in the study identified agroclimatic indicators. It is established that (data of the Dublyany meteorological station Lviv region, Zhovkva district) over the years of research, there is a tendency to increase the temperature and decrease the amount of precipitation and their extremely uneven distribution during the growing season, and, accordingly, their impact on productive reserves moisture in the arable $(0-30 \mathrm{~cm})$ layer of soil, which clearly indicates a change in climatic conditions in the western part of the Forest-Steppe of Ukraine (Fig. 1). 


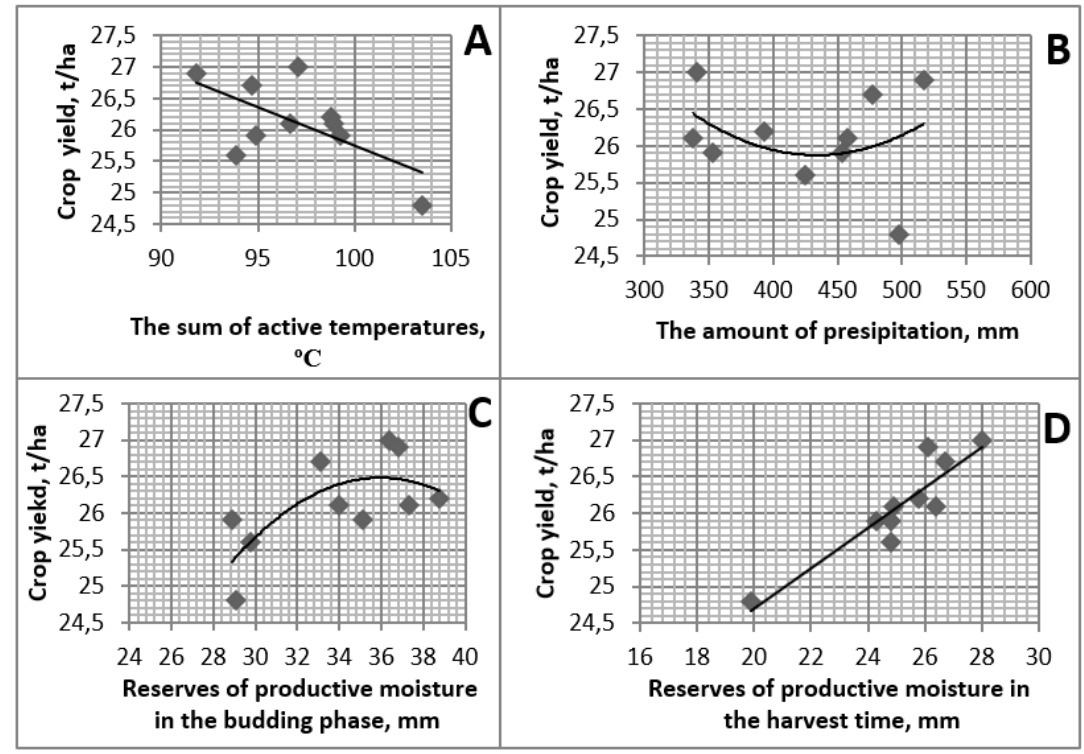

Fig. 1. Potato yield depending on climatic factors (average for 2011-2020): A - the sum of active temperatures during the growing season, ${ }^{\circ} \mathrm{C} ; \mathrm{B}$ - the amount of precipitation during the growing season of potatoes, $\mathrm{mm} ; \mathrm{C}$ - reserves of productive moisture in the arable $(0-30 \mathrm{~cm})$ layer of soil in the budding phase, $\mathrm{mm}$; D - reserves of productive moisture in the arable $(0-30 \mathrm{~cm})$ layer of soil at harvest time, $\mathrm{mm}$

Given the variability of climatic indicators, in particular, such as the sum of active temperatures during the potato growing season, precipitation, productive moisture reserves in the arable soil layer $(0-30 \mathrm{~cm})$, we performed statistical calculations of the probability of their impact on crop yields and obtained multiple regression equations:

$$
\mathrm{Y}=10.7573+0.3582 \mathrm{X}_{1}+0.01753 \mathrm{X}_{2}+0.00472 \mathrm{X}_{3}+0.03861 \mathrm{X}_{4}
$$

where $X_{1}$ - reserves of productive moisture in the arable soil layer $(0-30 \mathrm{~cm})$ in the budding phase of potatoes $(\mathrm{mm}), \mathrm{X}_{2}$ - reserves of productive moisture in the arable soil layer $(0-30 \mathrm{~cm})$ at the time of harvesting potato tubers $(\mathrm{mm}), \mathrm{X}_{3}$ - the amount of precipitation during the potato growing season $(\mathrm{mm}), \mathrm{X}_{4}$ - the sum of active temperatures during the potato growing season $\left({ }^{0} \mathrm{C}\right)$.

Based on the performed calculations, a matrix of paired correlation coefficients $\mathrm{R}$ is obtained:

Table 1. Matrix of paired correlation coefficients R.

\begin{tabular}{|c|c|c|c|c|c|}
\hline- & $\mathrm{y}$ & $\mathrm{x}_{1}$ & $\mathrm{x}_{2}$ & $\mathrm{x}_{3}$ & $\mathrm{x}_{4}$ \\
\hline $\mathrm{y}$ & 1 & 0.9104 & 0.6426 & -0.1555 & -0.6205 \\
\hline $\mathrm{x}_{1}$ & 0.9104 & 1 & 0.5924 & -0.4616 & -0.5632 \\
\hline $\mathrm{x}_{2}$ & 0.6426 & 0.5924 & 1 & -0.2882 & -0.09401 \\
\hline $\mathrm{x}_{3}$ & -0.1555 & -0.4616 & -0.2882 & 1 & -0.2963 \\
\hline $\mathrm{x}_{4}$ & -0.6205 & -0.5632 & -0.09401 & -0.2963 & 1 \\
\hline
\end{tabular}

The practical significance of the multiple regression equation is estimated using the multiple correlation index and its square - the coefficient of determination. 
The multiple correlation index characterizes the close connection of the specified set of factors with the studied feature, or, alternatively, assesses the closeness of the joint influence of factors on the result.

The multiple correlation coefficient (Multiple Correlation Index) is:

$$
R=\sqrt{1-\frac{s_{e}^{2}}{\sum\left(y_{i}-\bar{y}\right)^{2}}}=\sqrt{1-\frac{0.214}{3.84}}=0.9717
$$

The relationship between trait $\mathrm{Y}$ and factors $\mathrm{Xi}$ is strong. The coefficient of determination is $\mathrm{R} 2=0.97172=0.9442$.

It was also found that the greatest influence on the result of Y (yield) has a factor X1 (reserves of productive moisture in the arable soil layer $(0-30 \mathrm{~cm})$ in the budding phase of potatoes) - the correlation coefficient is 0.9104 .

\section{Conclusions}

A comprehensive analysis of the influence of climatic factors made it possible to establish that there is a strong relationship between the studied factors and the yield of potato tubers. Of particular importance are the reserves of soil moisture in the arable soil layer $(0-30 \mathrm{~cm})$ in the budding phase of potatoes, namely during the period of mass tuber formation, which was confirmed by our research (correlation coefficient 0.9104 ).

The study of the problem of the influence of climatic factors on the conditions of formation of productivity of agrocenoses has important ecological and national economic value as the estimation of dynamics of productivity of the main crops of Ukraine according to change of meteorological factors is especially actual in the conditions of global climate changes.

\section{References}

1. I. Karimov, Information and computing systems in economics, 250 (2009)

2. M. Kul'bida, T. Adamenko, Ahrometeorolohichnyy ohlyad po terytoriyi Ukrayiny za 2002-2003 sil's'kohospodars'kyy rik, 39 (2003)

3. M. Barabash, L. Tkach, Nauk. zap. Vinnyts'koho. derzh. ped. un-tu. Seriya: Heohrafiya, 9, 23 (2005)

4. V. Dukhovnyy, S. Nerozin, G. Stulina, G. Solodkiy, Crop yield programming (a systematic approach applied to land reclamation), 185 (2015)

5. V. Pepelyaev, O. Golodnikov, N. Golodnikova, Cybernetics and computer technologies, 1, 53 (2020)

6. I. Shuvar, H. Korpita, Agribusiness, In the fight for the harvest, 6(65), 28 (2020)

7. I. Shuvar, H. Korpita, Folia Pomer. Univ. Technol. Stetin., Agric., Aliment., Pisc., 355(54)2, 31 (2020)

8. M. Romashchenko, O. Sobko, D. Savchuk, M. Kul'bida, Pro deyaki zavdannya ahrarnoyi nauky u zv"yazku zi zminamy klimatu, 46 (2003)

9. D. Wallach, D. Makowski, J. Jones, F. Brun, Working with Dynamic Crop Models, Methods, 504 (2014)

10. S. Holod, Newsletter to the Center for Scientific Safety of the APV of Kharkiv Oblast, 20, 75 (2016) http://nbuv.gov.ua 
11. A. Shastry, H.A. Sanjay, E. Bhanusree, International Journal of Soft Computing, 12(2), 96 (2017) https://medwelljournals.com

12. Final report "On research work on the development of scenarios for climate change in Ukraine in the medium and long term using data from global and regional models.", https://uhmi.org.ua

13. T. Klein et al, International Journal of Climatology, 22, 1441 (2002)

14. Yu. Yarosh, B. Trusov, Technology of agricultural production, 524 (2005)

15. I. Shuvar, I. Boyko, Naukovyy visnyk NUBiP Ukrayiny, 162, 27 (2011)

16. I. Shuvar, V. Gudz, A. Shuvar, O. Krushyns'kyy, Ecological and herbological monitoring and forecast in agrocenoses (2011)

17. I. Shuvar, H. Korpita, "ScienceRise", 9/1 (26), 39 (2016)

18. I. Shuvar, H. Korpita, Zbirnyk naukovykh prats natsionalnoho naukovoho tsentru "Instytut zemlerobstva NAAN, 3-4, 71 (2016)

19. I. Shuvar, H. Korpita, A. Yunyk, Produktyvnist' yachmenyu yaroho i kartopli $v$ ahrotsenozakh zakhidnoho Lisostepu Ukrayiny: monohrafiya, 152 (2019)

20. I. Shuvar, H. Korpita, Agribusiness, Reduce weediness, 3(62), 40 (2020)

21. L. Tkach, M. Barabash, Kolyvannya klimatu Ukrayiny vidnosno zahal'noyi tendentsiyi zminy klimatu na nayblyzhche maybutnye, 2(12), 85 (2005) 